\title{
COMMENTS
}

\section{INDIAN REGULATIONS ON ETHICS AND THEIR IMPACT ON COURT CASE BACKLOGS}

\author{
SUSHANT CHANDRA, \\ Jindal Global Law School (Sonipat, India)
}

DOI: $10.21684 / 2412-2343-2017-4-1-72-83$

The paper aims to explore the role of ethics regulations on the backlog of cases in the state of Uttar Pradesh, India. There, there are many local practices which hinder the disposal of cases in the courts. The paper examines several, beginning with the theoretical training in ethics at the law schools and its impact in practice. The paper then explores the legal status of strikes and how they are conceived by lawyers in delaying the disposal of cases. Next it deals with adjournments in the courts and unravels the myriad frivolous reasons cited in seeking adjournments, as well as how, despite statutory limitations, courts succumb to the pressure of the Bar in granting them. The author echoes concern for creating transparency, efficiency and a system that inspires integrity, and argues for the need to rethink and redesign the whole system and create independent tribunals to enquire into lawyers guilty of professional misconduct.

Keywords: case backlog; court delays; ethics regulations.

Recommended citation: Sushant Chandra, Indian Regulations on Ethics and Their Impact on Court Case Backlogs, 4(1) BRICS Law Journal 72-83 (2017).

\section{Introduction}

The state of Uttar Pradesh is the most populous state in India with seventyfive districts under eighteen subdivisions. The 2011 census stated a mammoth 200 million as the population of the state. The state has the highest case backlog 
with around 4.8 million cases pending in different courts. This constitutes around 23 percent of the total nationwide pendency - which is estimated at around 20 million cases.' 'While the national average of case burden is 1,350 cases per judge, in the state of Uttar Pradesh it is double, at around 2,500 cases per judge. ${ }^{2}$ Out of these 4.8 million cases, around 0.63 million have been pending for more than ten years. ${ }^{3}$ The courts in Uttar Pradesh dispose of around 44,571 cases each month, which is five times higher than the national average. ${ }^{4}$ Two major reasons which are frequently given to explain the delayed disposal of cases are: the smaller number of judges and the lack of accountability, which significantly reduce the efficiency in the system. The $245^{\text {th }}$ Report of the Law Commission was assertive in tone and clear in objective when it emphasized that for paving the way for "access to justice," a constitutional obligation, it was imperative to "increase judges' strength," reach a "breakeven" point and "dispose of the backlog in a 3-year timeframe".5 Agreeing to this, in October 2015, a seven-judge panel of the Allahabad (Uttar Pradesh) High Court directed the state government to increase the total number of judges in the subordinate courts by 25 percent so as to expeditiously dispose of the pending cases. ${ }^{6}$

The Bar Council of India (BCl) Rules on Professional Standards and Etiquette spell out a number of ethical duties, the breach of which constitutes professional misconduct. In addition to preserving the nobility of the profession, it is also intended that cases be expeditiously disposed of and access to justice secured. The evolution of the legal system has witnessed a narrative counter to the envisaged outcome. This paper attempts to examine that nexus.

\section{Researchers and Data Collection}

A team of three people conducted the field research over a span of four months. All team members were part of the Clinical Legal Aid Society at the Jindal Global Law School, Delhi, India. Data collection took place from December to January 2015-2016 and May to June 2016. The data were collected from two districts of

1 Shobhit Mathur \& Nomesh Bolia, Twenty Million Cases are Still Pending: In India's District Courts, a Crisis is Revealed, Firstpost.com, April 5, 2016 (Feb. 20, 2017), available at http://www.firstpost.com/india/ twenty-million-cases-still-pending-in-indias-district-courts-a-crisis-is-revealed-2712890.html. See also Arvind Chauhan, UP Tops the List of Pending Cases in Courts across India, The Times of India, November 2, 2015 (Feb. 20, 2017), available at http://timesofindia.indiatimes.com/india/UP-tops-the-list-of-pendingcases-in-courts-across-India/articleshow/49632177.cms.

2 Id.

3 Id.

4 Id.

$5245^{\text {th }}$ Report of the Law Commission of India (July 2014), at 54 (Feb. 20, 2017), available at http:// lawcommissionofindia.nic.in/reports/Report245.pdf.

6 Chauhan, supra note 1. 
Uttar Pradesh. Data collection was done using ethnographic observations - using interviews with respondents - on various questions relating to ethical regulations. The interviews were conducted primarily on court premises and in the offices of lawyers and judges.

\title{
2. $\mathrm{BCl}$ - The Regulator of Ethics Has Failed the System
}

"Quality" is the catchword which must form the bulwark of the legal profession. So expounded the Law Commission of India in its $184^{\text {th }}$ Report while granting recognition to new law schools. ${ }^{7}$ The Law Commission was mindful of the deterioration in the quality of lawyers and the role the ethical regulator had in this development. While acknowledging that the Bar Council was culpable in contributing to the compromise in the quality of education, the Law Commission cast more serious aspersions on the functioning of the Bar Council, in paras. 8.6 and 8.7 of the Report, wherein it observed:

\begin{abstract}
8.6. There are again complaints that some inspections are cursory and colleges which are badly run are given clean chit while colleges which are running well and whose students have consistently obtained first ranks in the University or whose students have consistently been selected by reputed universities in UK and USA for post graduate studies, are disaffiliated.

8.7. There are indeed several court cases filed by managements against the Bar Council of India and while no doubt some have been dismissed, some have been allowed with critical observations against the manner in which inspections were conducted or disaffiliation proposed. The law reports of the High Courts are evidence to these facts.
\end{abstract}

However, the situation has not changed much since these critical observations were made by the Law Commission in its $184^{\text {th }}$ Report in 2002. A recent disagreement between the $\mathrm{BCl}$ and the Faculty of Law, Delhi University (one of the finest law schools in the country) touches upon the point. When recently the $\mathrm{BCl}$ disaffiliated the Faculty of Law, Delhi University, the Dean of the Faculty took serious issue with the $\mathrm{BCl}$, and referred to the Report as "silly" and to the members as "jokers." The character of the issue can be comprehended by the statement of the Dean when he said:

\footnotetext{
Law Commission of India, Dec. 2002, $184^{\text {th }}$ Report on the Legal Education \& Professional Training and Proposals for Amendment to the Advocates Act, 1961 and the University Grants Commission Act, 1956. On page 77 of the $184^{\text {th }}$ Report, the Law Commission of India observed: "In India, we do require a good number of law schools but they must produce students who have received legal education of sufficient quality" (Feb. 20, 2017), available at http://lawcommissionofindia.nic.in/reports/184threportparti.pdf.

8 Will not Bow: Delhi University Dean Rails against BCI "Jokers" Again Refusing Accreditation over "Small Idiotic Things," Legally India, February 4, 2015 (Feb. 20, 2017), available at http://www.legallyindia.com/ Law-schools/delhi-university-to-show-cause-why-it-deserves-recognition-after-bad-report-card.
} 
There are 1,200 law colleges which they [the $\mathrm{BCl}$ ] do not inspect. No single class happens at those law colleges. So many things are there in relation to faculties of law and in relation to law education.

\subsection{Consequential Conception of Ethics v. Formative Ethics}

If taken on record, 1,200 colleges is a staggering number. This begs an inquiry into a deeper question related to what is referred to in this paper as the consequential conception of ethics and formative ethics. The theoretical notion of ethics forms the basis of the consequential conception of ethics in India. The theoretical notion of ethics is motivated by the guiding principle that a theoretical course on ethics would suffice in installing a "master key" to unlock all ethical dilemmas encountered by law students. The Bar Council's committee on legal education, which sets the syllabus for law schools, in its wisdom, has prescribed a course on ethics to be taught in the final semester at the law school. It is observed that by the time a student reaches the final semester there is a clear lack of motivation to study a course which does not align with the student's area(s) of interest. ${ }^{10}$ This deters achieving the desired outcome. There is a need to redesign the system on how we think about ethics in the law schools. This consequential conception of ethics has clearly failed to offer any cogent impetus in creating a fair legal system. The prospective inquiry must subsume claims related to bridging the chasm between ethical formulations within law schools and the creation of a fair legal system. The following study is illustrative of our failed institutional endeavour. The concept of formative ethics appeals much. The question of design, that it deals with, requires ethical values to be blended with the courses and training across the law schools. This may allow enthused interest to be sustained, with a long-lasting impact on the outcome intended to be achieved, of creating a fair legal system. A "rule"-driven system may be easily circumvented, but a "principle"-driven system, which has a stronger appeal to rationality, may not be.

\subsection{Survey in Uttar Pradesh}

A pilot study of 200 lawyers was taken up across the districts of Allahabad, Kanpur, Lucknow and Varanasi, all in the state of Uttar Pradesh. The surveys at Allahabad and Lucknow are complete while they are still underway at Kanpur and Varanasi. The study aimed at exploring the nuances of interface between discourse related to professional ethics at the law school and its impact in the courts. In the first part of the study the intention was to explore the impact of ethical regulations on the conduct of lawyers, and hence the questions were designed accordingly. Most of

9 Will not Bow, supra note 8.

10 Author's note: The survey was conducted during my last two classes on Professional Ethics in 2015 and 2016, comprising a total of 120 students, and around 115 expressed lack of motivation to study a course on Professional Ethics in the final semester. 
the lawyers seemed appalled at the shoddy implementation of ethical regulations, which is something looked into later in this paper.

As alluded to earlier, there is all-pervasive scepticism regarding the quality of legal education in India, hence the lawyers were asked whether they had been taught any courses related to professional ethics. Forty lawyers at Allahabad and thirty at Lucknow answered the question in the negative. However, the remaining ten lawyers at Allahabad and twenty at Lucknow had been taught a course on professional ethics." Almost none of them, though, could answer as to the content of the course taught to them.

The thirty lawyers who had received training were asked whether they were aware of the Bar Council of India Rules on Professional Standards and Etiquette under the Advocates Act, 1961. Forty-five lawyers from Allahabad and forty-eight from Lucknow were aware of some Bar Council rules that governed them, but they did not know the exact titles of the regulations. The lawyers were asked about the content of the $\mathrm{BCl}$ Rules on Professional Standards and Etiquette - to which forty lawyers at Allahabad and forty-five at Lucknow gave generic answers. They did not seem to be aware of provisions related to contingency fees, conflicts of interest and duty towards the client, either. One of the respondent lawyers said:

The state departments are never interested in disposals. They even delay our compensation. The inordinate delay is inevitable. ${ }^{12}$

However, two lawyers at Allahabad and one at Lucknow were aware of the provisions under the $\mathrm{BCl}$ Rules on Professional Standards and Etiquette.

\subsection{Three-Pronged Approach - Content, Compliance and Consequence}

The dismal portrayal of the lawyers' understanding of the content on professional ethics is disappointing. The survey adopted this three-pronged approach to build upon our understanding of the impact of professional ethics on the conduct of lawyers. It is disturbing to observe that around 70 percent of the lawyers surveyed had not studied any courses related to professional ethics/formation, especially when this is a mandatory requirement as prescribed by the $\mathrm{BCl}$ committee on legal education. It was equally shocking to note that around 85 percent of lawyers had no idea of the mandatory $\mathrm{BCl}$ Rules on Professional Ethics and Standards. The survey clearly marks the problem at the inception stage - of imparting education at the law schools - where compulsory requirements related to professional ethics courses are clearly not fulfilled.

\footnotetext{
11 The responses were sought from the respondents in the months of December and January of 2015.

12 Interview with the research team on December 10, 2015.
} 


\section{Practice of Strike and the Backlog of Cases}

The word "right" associated with strikes by lawyers in India is oxymoronic. The public value of "administration of justice" and the parallel liberty of "access to justice" are agreed to be quintessential aspects of the Indian legal system. ${ }^{13}$ A lawyer is obligated to always "fearlessly uphold the interest of his client" under the preamble to the $\mathrm{BCI}$ Rules on Professional Standards and Etiquette. The spirit is given due place under clause 15 of the Rules, which provides:

It shall be the duty of an Advocate fearlessly to uphold the interests of his client by all fair and honorable means without regard to any unpleasant consequences to himself or any other.

The moot question is: When legal principle, statutory duty and constitutional right all speak in one voice against the strike by lawyers, then why do lawyers go on strike? And if they do, then, what sanctions are imposed on them for resorting to such an illegal practice? There have been instances where planned and coordinated strikes have been conducted by lawyers. But the disciplinary authorities are in dire straits. The lawyers at Jodhpur have been persistently observing strike on the last working day of every month for the past thirty-nine years. This is to protest the creation of a High Court bench at Jaipur, eventually leading to the sharing of clientele of the lawyers between both cities. ${ }^{14}$ The district court in Meerut (western Uttar Pradesh) has been observing strike every Saturday for the past fifteen years. ${ }^{15}$ This again is done in view of their demand to create another bench of the Allahabad High Court in Meerut. ${ }^{16}$ It is the "public utility flavour ${ }^{117}$ which distinguishes the practice of law from other professional activities. It is against this background, contextually, that the duties of lawyers to litigants and courts must be interpreted..$^{18}$ The fundamental liberties of life and profession are subject to reasonable restriction under the Indian

13 For a detailed understanding of liberty of access to justice, please see Sushant Chandra \& Nityash Solanki, Legal Aid in India: Retuning Philosophical Chords, 2(2) BRICS Law Journal 68-85 (2015).

14 Jodhpur Lawyers Protest Demand for HC Bench in Udaipur, The Times of India, August 15, 2009 (Feb. 11, 2017), available at http://timesofindia.indiatimes.com/city/jaipur/Jodhpur-lawyers-protest-demandfor-HC-Bench-in-Udaipur/articleshow/4895325.cms.

15 Can the SC Do Anything about Frequent Strikes by Lawyers?, Mint, October 6, 2015 (Feb. 20, 2017), available at http://www.livemint.com/Politics/DIQyJ9qcsdrC9k99DDO0VJ/Can-the-SC-do-anythingabout-frequent-strikes-by-lawyers.html.

16 Decision on HC Bench in Western UP after Delhi Polls, The Hindu, February 1, 2015 (Feb. 20, 2017), available at http://www.thehindu.com/news/national/other-states/decision-on-hc-bench-in-westernup-after-delhi-polls/article6843040.ece.

17 Indian Council of Legal Aid and Advice v. Union of India (1995) 1 SCC 732.

18 Ex. Capt. Harish Uppal v. Union of India 1994 SCC Supl. (2) 195. 
Constitution. The Supreme Court of India has categorically held that there is no right to strike by lawyers. ${ }^{19}$

\subsection{Strike in Uttar Pradesh}

The survey formulated few questions on strike and its role with regard to the backlog of cases. The survey sample comprised interviews with 200 lawyers. $^{20}$ Additionally, this time ten judges were interviewed in order to hear the view from the other side. ${ }^{21}$ The interview began with a generic question on what they thought about the appropriateness of strikes. Thirty lawyers at Allahabad and twenty-five at Lucknow justified going on strike, whereas twenty lawyers at Allahabad and twentyfive at Lucknow disagreed with the concept of strike. Those who agreed with strikes were asked a couple of attached questions. The first question dealt with what reasons would they give for justifying strikes; and the second dealt with how long, according to them, a lawyer should be permitted to go on strike. As part of a second sub-question, they were given the following options - a few hours, one day, a few days or until their demands were met. Fifteen lawyers at Allahabad and twenty at Lucknow justified going on strike mostly on the grounds of making themselves heard or expressing their grievances before the authorities, and they thought strike was the most convenient way of doing so. They believed any demand with numbers on their side could be easily obtained. One of the ex-secretaries of the Bar Association said:

The authorities have a deaf ear and they dictate everything they wish to. Strike is the most effective way of getting our demands realised. ${ }^{22}$

The remaining responses were more contextual and varied depending upon the purpose for which the strike was called. But most of the remaining responses could be grouped under "getting demands fulfilled" by the authorities. This ranged from getting compensation for an aggrieved lawyer to getting medical insurance to not letting a parallel High Court bench set up in any other district. To the second subquestion on the duration of a strike, twenty-six lawyers at Allahabad and twenty-two at Lucknow specified that they did not mind continuing a strike until their demands

19 Ex. Capt. Harish Uppal v. Union of India 1994 SCC Supl. (2) 195.

20 The responses were sought in the months of May and June 2016.

21 Author's note: We also went to watch the proceedings at the Central Administrative Tribunal in Civil Lines at Allahabad during the month of January 2016. In the first proceeding, we arrived at 10 a.m. the scheduled time when the Tribunal should be seated and commence proceedings. However, the Bench sat at 12.30 p.m. instead. There was a commotion, though. We asked a few lawyers about the commotion and we were told that "reference" had happened. "Reference" is a local customary practice of lawyers wherein they mourn the death of another lawyer by boycotting all legal work for a day. The President of the Bar made a speech about the deceased lawyer before the Tribunal, and after that the Chairperson of the Tribunal also made a speech mourning the death of the deceased.

22 Interview given to the research team on June 15, 2016. 
were met by the authorities, while a minority of responses favoured continuing a token strike for a few hours, one day, or even a few days.

The second set of questions dealt with their awareness of the laws on strike and punishment. The lawyers were asked whether they knew about the laws relating to strikes. Thirty-eight lawyers at Allahabad and twenty-four at Lucknow knew that there was no right to strike and that it was illegal to do so. However, only three lawyers at Allahabad and seven at Lucknow could recall the exact Supreme Court judgments on strikes. The lawyers were also asked about the punishment that might be imposed in case of a strike. Almost none had any idea about the punishment. Questioned further on this aspect, those who responded said that the state Bar Council almost never took any action against the lawyers and if the High Court initiated a contempt proceeding, then they let off lawyers by accepting a simple apology. Hence, the lawyers had no idea about the nature of possible punishment.

The third set of questions dealt with understanding the perspective of lawyers on the plight of litigants and their views on the administration of justice. They were asked whether a strike would lead to increasing the backlog of cases. A surprising forty-five lawyers at Allahabad and forty-three at Lucknow said that it would.

It was observed that the institutional design clearly made lawyers insensitive to the plight of litigants. The lawyers had an external view of the litigants' distress, but clearly failed to appreciate their objective right to speedy justice and the importance of the public value of the administration of justice. The chasm between how the courts view strikes and how lawyers view them was clearly visible.

\section{Frequent Adjournments and the Backlog of Cases}

The adjournment culture has diminished the efficiency of the courts and hindered the liberty of speedy access to justice by litigants. There have been all sorts of reasons offered - from bleak to cogent - and sometimes no reasons at all for seeking adjournments. The character of the issue can be gauged by a recent observation made by a sitting Judge of the Indian Supreme Court who, on the absence of an Additional Solicitor General of India, observed: ${ }^{23}$

Two Supreme Court judges have no other job but to come and sit here and stare at the clock and watch time ticking by...

The adjournment, originally with the cult status of an "art," has been reduced to a "delaying strategy" by counsels at court. The mockery accentuates when the

23 Murali Krishnan, Two SC Judges Have No Other Job But to Sit and Stare at the Clock - SC to Additional Solicitor General in Drought Case, Bar and Bench, April 7, 2016 (Feb. 20, 2017), available at http:// barandbench.com/two-sc-judges-no-job-sit-stare-clock-sc-comes-heavily-centre-asg-pinky-anandabsence-drought-case/. 
lawyers do not empathize with the plight of the litigants. This only adds insult to injury. The culture of adjournment besieges every small court proceedings known. It is sought when the witness has to depose, when documents are to be filed, when counter affidavits or rejoinders have to be filed, when a lawyer is ill, when a lawyer is travelling, and so on for an unlimited number of specious excuses. The statutory scheme clearly proscribes granting more than three adjournments and further clearly demands a "specific reason" for granting one..$^{24}$ But to no avail. There is lax enforcement of this provision by the courts. An attempt that was made to analyse the culture of adjournment in Uttar Pradesh is described next.

\subsection{Adjournment in Uttar Pradesh}

Ten judges each at the Allahabad and Lucknow High Courts were surveyed in order to understand the reasons for adjournments. The responses could be marshalled under the following five categories:

a. The lawyers were not adequately prepared.

b. The lawyers were ill.

c. The lawyers were out of station for official work.

d. A family member of a lawyer was ill.

e. Someone passed away in the family of a lawyer.

The judges were asked which reasons were cited most frequently by lawyers and to rate these reasons on a scale from one to five. The most often cited reason for seeking an adjournment in the courts was for illness. Eight judges said this. The second most cited reason was "out of station" for official work. This was stated by seven judges. Eight judges mentioned "inadequate preparation" as the third most cited reason for seeking an adjournment.

Next, questions were asked of lawyers in both of the districts. These questions were related to their ethical responsibility regarding adjournment. They were asked whether they felt justified in seeking frequent adjournments. Forty lawyers at Allahabad and forty-five at Lucknow said they never sought frivolous adjournments. When asked the reason for seeking an adjournment, most of the responses given were fell under the following two categories:

a. Engagement in other courts, and these were fresh matters.

b. Illness.

It was curious to observe that only a negligible number of the lawyers cited other reasons for seeking adjournments than were given by the judges. One of the lawyers responded:

You have to justify the fee that you take from your client. You can't leave him in the doldrums. I see nothing wrong in appearing in fresh matters if it conflicts with a listed one.

24 Krishnan, supra note 23. 
Ten lawyers at Allahabad and seventeen at Lucknow said they never sought frivolous adjournments and refused to cite a reason. Twenty lawyers at Allahabad and nineteen at Lucknow said they never sought frivolous adjournments and gave"appearance in other courts" as the most frequently used reason for seeking an adjournment. Ten lawyers at Allahabad and nine at Lucknow said they never sought frivolous adjournments and cited illness as the most frequently used reason for an adjournment.

However, ten lawyers at Allahabad and five at Lucknow, on the strict condition of anonymity, did confess that sometimes frivolous adjournments were sought from the court. But they said this was always done in the best interest of the client. By this they meant not putting the matter up for hearing before an "unfavourable court" constituted acting in the best interest of the client. A lawyer in a second appeal took few adjournments where a question of law had to be framed for the appeal to be admitted. He deliberately was getting the matter adjourned. He responded:

If we wouldn't have sought the adjournment from the court, then the court would have certainly dismissed the matter on account of [a] weak substantial question of law. Hence, we waited until a favourable judge was there and got the appeal admitted.

In the Allahabad High Court, it takes around twenty years for a hearing to commence in the admitted second appeals. Until then, the status quo has to be maintained. The same lawyer was further asked what if he requested the court to dispose of the matter expeditiously. He responded:

That certainly could be done. In fact many tried doing this earlier by filing an application before the Chief Justice's court and the Chief Justice consented to it. This led to inundation of similar application before the Chief Justice and he had to take a policy decision of not admitting anyone's application for expeditious disposal of second appeals. It should be decided only in due course. ${ }^{25}$

There were instances of mutual cooperation between judicial officers and members of the Bar in adjourning the proceedings too. ${ }^{26}$

25 Interview given to the Research Team on May 20, 2016.

26 Author's note: Following the events mentioned earlier, supra note 21, we heard a number of lawyers murmuring about the whereabouts of the deceased lawyer and the most insidious comment was what occurred next - when a prominent member of the Bar asked the others in a light vein whether the others had ever seen the deceased practise in the court. To which they all laughed and then dispersed.

Our next visit to the Tribunal was marked by another "reference," when the members mourned at the demise of a retired Chief Justice of India - Mr Justice S.H. Kapadia. The proceedings were again adjourned for the day.

We observed that members of the Tribunal were extremely casual, with no sense of efficiency and time. The Bar was equally reluctant, with no sense of efficiency and ethical responsibilities. 


\section{Sanctions or Rather the Lack Thereof}

The royal debate between Hart and Austin portrays the oblique picture of the professional conduct of lawyers. The lack of proper education, proper training, understanding of laws and the screening process to join the Bar are all responsible for the frequent instances of professional misconduct in Uttar Pradesh. A critical reflective attitude towards ethical norms may not work out given the poor educational system and screening process.

In such a situation a sanction-driven approach may cater to ensuring professional conduct amongst lawyers. A retired Supreme Court Justice, Mr Justice Markandey Kathju, once observed in open court the following, regarding an appeal that had come to his court from the High Court of Uttar Pradesh:"There is something rotten at Allahabad (Uttar Pradesh) High Court."127

The idea behind taking the powers away from the High Court and vesting them in an independent regulator was to ensure the independence of the legal profession. ${ }^{28}$ The ideal of independence has clearly damaged the integrity which was intended to be protected. It was a holy balance which was intended, and not independence at the cost of integrity and efficiency. This has already been pointed out by many distinguished jurists, namely, that the disciplinary committee of the Bar Council has failed the country and there is a need to devise a system that admits the claims of efficiency, transparency and integrity along with independence.

There are voices calling for the creation of independent tribunals for adjudicating professional misconduct of lawyers. This would ensure keeping a check on bias in conducting transparent disciplinary proceedings.

\subsection{Consumer Protection Act}

The National Consumer Commission came out with a decision clearly roping in "services" by lawyers, under the Consumer Protection Act, 1986. The Commission picked up this line of reasoning from the nature of "services" rendered by doctors and argued that if the services rendered by doctors - being professionals - could be adjudicated positively by the National Consumer Commission, then there could not be any reason why services rendered by lawyers could not also be. ${ }^{29}$ However, this was appealed before the Supreme Court, which stayed the matter indefinitely.

This clearly reflects the need to rethink the sanctions imposed in instances of professional misconduct by lawyers.

27 Something Rotten in Allahabad High Court: Supreme Court, The Times of India, November 26, 2010 (Feb. 20, 2017), available at http://timesofindia.indiatimes.com/india/Something-rotten-in-AllahabadHigh-Court-Supreme-Court/articleshow/6994988.cms.

28 Law Commission of India, Oct. 1978, $75^{\text {th }}$ Report on Disciplinary Jurisdiction under the Advocates Act, 1961 (Feb. 20, 2017), available at http://lawcommissionofindia.nic.in/51-100/report75.pdf.

29 D.K. Gandhi v. M. Mathias, III (2007) CPJ 337 (NC). 


\section{Concluding Remarks}

The lack of integrity on the part of the Bar is clearly at the heart of the nexus between rules on professional ethics and the backlog of cases in the state.

For formative ethics to play a stellar role in embedding norms of professional ethics, the principles of ethics must be blended into courses and practical training across all the years of study and training in the law schools. This would ensure that crucial norms of professional ethics are discussed and debated and that they shape the practical understanding of the applicability of the law against the backdrop of a solution-oriented approach. The absence of any adequate recourse against going on strike by lawyers under the $\mathrm{BCI}$ Rules on Professional Standards and Etiquette is deeply troubling. There have been recurring suggestions made to the $\mathrm{BCl}$ to incorporate a rule against striking and for a strike to be recognized as "professional misconduct." The entry to the Bar must be made tougher and process-oriented institutions must be put in place to maintain a continuous check, ensuring efficiency and transparency in the functioning of the Bar. India stands at the crossroads of a transformation wherein debates on the entry of foreign law firms into India are incessant. This would certainly entail a deeper commitment from Indian stakeholders to ensure transparent, efficient and fair processes are in place. Any changes that are brought about must be directed in this way.

\section{References}

$245^{\text {th }}$ Report of the Law Commission of India (July 2014) (Feb. 20, 2017), available at http://lawcommissionofindia.nic.in/reports/Report245.pdf.

Chandra S. \& Solanki N. Legal Aid in India: Retuning Philosophical Chords, 2(2) BRICS Law Journal 68-85 (2015).

Chauhan A. UP Tops the List of Pending Cases in Courts across India, The Times of India, November 2, 2015 (Feb. 20, 2017), available at http://timesofindia. indiatimes.com/india/UP-tops-the-list-of-pending-cases-in-courts-across-India/ articleshow/49632177.cms.

Law Commission of India, Dec. 2002, $184^{\text {th }}$ Report on the Legal Education \& Professional Training and Proposals for Amendment to the Advocates Act, 1961 and the University Grants Commission Act, 1956 (Feb. 20, 2017), available at http:// lawcommissionofindia.nic.in/reports/184threport-parti.pdf.

\section{Information about the author}

Sushant Chandra (Sonipat, India) - Assistant Professor \& Assistant Director (Clinical Programme), Jindal Global Law School (Office No. 321, T-1, $3^{\text {rd }}$ Floor, Jindal Global Law School, O.P. Jindal Global University, Sonipat, Haryana, 131001, NCR of Delhi, India; e-mail: schandra@jgu.edu.in). 